\title{
A revision of Sunius XV. Six new species from Kyrgyzstan and the Himalaya, and additional records (Coleoptera: Staphylinidae: Paederinae)
}

\author{
With 26 figures \\ VOLKER ASSING ${ }^{1}$ \\ ${ }^{1}$ Gabelsbergerstraße 2, 30163 Hannover, Germany. - vassing.hann@t-online.de \\ Published on 2015-12-21
}

\section{Summary}

Six micropterous species of Sunius STEPHENs, 1829 are described and illustrated: S. alaianus spec. nov. (Kyrgyzstan) of the S. viator group; S. marratus spec. nov. (North India: West Bengal), S. virilis (North India: West Bengal), S. deplectens spec. nov. (North India: West Bengal), S. dearmatus spec. nov. (East Nepal), and S. migrus spec. nov. (Central Nepal), all five of them of the $S$. manasluensis group. Additional records of 16 species are reported both from the West and the East Palaearctic regions. The genus is now represented in the Palaearctic region by 126 described species and two subspecies.

\section{Key words}

Coleoptera, Staphylinidae, Paederinae, Medonina, Sunius, Palaearctic region, Kyrgyzstan, Himalaya, taxonomy, new species, new records, species groups

\section{Zusammenfassung}

Sechs brachyptere Arten der Gattung Sunius STEPHens, 1829 werden beschrieben und abgebildet: S. alaianus spec. nov. (Kyrgyzstan) aus der S. viator-Gruppe sowie S. marratus spec. nov. (Nordindien: Westbengalen), S. virilis (Nordindien: Westbengalen), S. deplectens spec. nov. (Nordindien: Westbengalen), S. dearmatus spec. nov. (Ostnepal) und S. migrus spec. nov. (Zentralnepal) aus der S. manasluensis-Gruppe. Weitere Nachweise von 16 Arten werden aus der West- und der Ostpaläarktis gemeldet. Die Gattung ist derzeit mit 126 beschriebenen Arten und zwei Unterarten in der Paläarktis vertreten.

\section{Introduction}

According to the latest contribution to the revision of Sunius Stephens, 1829, the genus was represented in the Palaearctic region by 116 species and two subspecies (Assing 2011c). In the meantime, four additional species have been described from the Greek islands Crete, Rhodes, and Samos (Assing 2013a, 2013b, 2015, in press). The vast majority of taxa (109 species and two

subspecies) is confined to the West Palaearctic (including Middle Asia), with the trans-Palaearctic distribution of one species extending eastwards to the Russian Far East. Only few species have been recorded from the Himalaya and from China. A catalogue and a key to species were provided by Assing (2011b). 
The present paper is based on material from various collections that has become available in the past few years. With one exception, all the newly described species were found among unidentified material of Neosclerus CAMEron, 1924 in the collections of the Muséum d'Histoire Naturelle, Genève.

\section{Material and methods}

The material treated in this study is deposited in the following collections: MHNG Muséum d'Histoire Naturelle, Genève
(G. Cuccodoro)

MNHUB Museum für Naturkunde der HumboldtUniversität Berlin (J. Frisch, J. Willers)

NHMB Naturhistorisches Museum Basel (M. Geiser, I. Zürcher)

NHMW Naturhistorisches Museum Wien (H. Schillhammer)

NME Naturkundemuseum Erfurt (M. Hartmann)

cAss author's private collection

cSch private collection Michael Schülke, Berlin

cSha private collection Alexey Shavrin, Daugavpils

cSme private collection Aleš Smetana, Ottawa

The morphological studies were conducted using a Stemi SV 11 microscope (Zeiss Germany) and a Jenalab compound microscope (Carl Zeiss Jena). The images of external characters were created using a photographing device constructed by Arved Lompe (Nienburg) and CombineZ software. A digital camera (Nikon Coolpix 995) was used for the remaining photographs.

Body length was measured from the anterior margin of the mandibles (in resting position) to the abdominal apex, the length of the forebody from the anterior margin of the mandibles to the posterior margin of the elytra, head length from the anterior margin of the frons to the posterior constriction of the head, elytral length at the suture from the apex of the scutellum to the posterior margin of the elytra (at the suture), and the length of the aedeagus from the apex of the ventral process to the base of the aedeagal capsule. The "parameral" side (i.e., the side where the sperm duct enters) is referred to as the ventral, the opposite side as the dorsal aspect.

\section{Descriptions and additional records}

\section{Sunius fallax (LoKAY, 1919)}

Material examined: Greece: 3 exs., Crete, south coast, Frangokastello, $35^{\circ} 11^{\prime} \mathrm{N}, 24^{\circ} 13^{\prime} \mathrm{E}, 5 \mathrm{~m}$, at light, 13.V.2008, leg. Schnitter (NME, cAss).
Comment: Sunius fallax is widespread and rather common in southeastern Europe. It has repeatedly been reported from Crete (Assing 2008a, 2013, 2015).

\section{Sunius propinquus (BRISOUT DE BARNEVILLE, 1867)}

Material examined: Morocco: 1 ex., Tetouan, $600 \mathrm{~m}$, 25.V.1994, leg. Majzlan (NHMW). Spain: 4 exs., Madrid, 10 km NW Tres Cantos, 22.-23.VII.2011, leg. Anichtchenko (cSha, cAss). Portugal: 2 exs., Algarve, Armacao de Pera, coast, 3.V.1998, leg. Hieke \& Wendt (MNHUB, cAss); 1 ex., Algarve, Serra Monchique, Fóia Mt., 800 m, 1.V.1998, leg. Hieke \& Wendt (MNHUB).

Comment: The Atlanto-Mediterranean distribution of $S$. propinquus ranges from the Western Mediterranean (Northwest Africa, Iberian Peninsula), the Azores, and Madeira to Italy and western Central Europe. For a distribution map see Assing (2008a).

\section{Sunius ovaliceps (FAUVEL, 1878)}

Material examined: Morocco: 1 ex., Oukaimeden district, Ait-Lekak village area, $31^{\circ} 17^{\prime} \mathrm{N}, 7^{\circ} 49^{\prime} \mathrm{W}, 1650 \mathrm{~m}$, leg. Anichtchenko (cSha). Spain: 6 exs., Alicante, NW El Castell de Guadalest, $1 \mathrm{~km}$ W Beniarda, $38^{\circ} 41^{\prime} \mathrm{N}$, $0^{\circ} 13^{\prime} \mathrm{W}, 550 \mathrm{~m}, 25 . X I .2013$, leg. Forcke (MNHUB, cAss); 4 exs. [teneral], Alicante, W Benigembla, Pla de Petracos, $38^{\circ} 46^{\prime} \mathrm{N}, 0^{\circ} 11^{\prime} \mathrm{W}, 470 \mathrm{~m}, 23 . \mathrm{XI} .2013$, leg. Forcke (MNHUB); 5 exs. [partly teneral], Alicante, W Benigembla, Pla de Petracos, $38^{\circ} 46^{\prime} \mathrm{N}, 0^{\circ} 11^{\prime} \mathrm{W}, 475 \mathrm{~m}$, 19.XI.2013, leg. Forcke (MNHUB); 10 exs. [partly teneral], Alicante, W Benigembla, Bco. de Malafi, $38^{\circ} 46^{\prime} \mathrm{N}$, $0^{\circ} 12 ' \mathrm{~W}, 520 \mathrm{~m}, 29 . \mathrm{XI} .2013$, leg. Forcke (MNHUB, cAss). France: 1 ex., Beziers, Portiragnes Plage, 8.X.1996, leg. Ziegler (NME).

Comment: Like the preceding species, $S$. ovaliceps has an Atlanto-Mediterranean distribution, which is illustrated in Assing (2008a).

\section{Sunius hellenicus (CoIfFAIT, 1961)}

Material examined: Greece: $1 \sigma^{\star}$, Pelopónnisos, NW Panapoulos, $37^{\circ} 49^{\prime} \mathrm{N}, 21^{\circ} 40^{\prime} \mathrm{E}, 540 \mathrm{~m}$, oak forest, 23.IV.3.V.2007, leg. Schnitter \& Arndt (NME).

Comment: The confirmed distribution of S. hellenicus is confined to Corfu and the Pelopónnisos, Greece. For a distribution map see Assing (2008a). 


\section{Sunius khnzoriani (CoIfFAIt, 1970)}

Material examined: Iran: $10^{\star}$, Ardabil province, $15 \mathrm{~km}$ S Germi, Beldashi, 38 ${ }^{\circ} 58^{\prime} \mathrm{N}, 48^{\circ} 00^{\prime} \mathrm{E}, 1270$ m, 12.X.2011, leg. Frisch (MNHUB).

Comment: This species has been recorded from Armenia, Turkey, Iran, and Georgia. Its distribution is mapped in Assing (2008a).

\section{Sunius fulgocephalus (ColfFalT, 1970)}

Material examined: Iran: Teheran: 1 ex., Karaj, University of Agriculture, $35^{\circ} 48^{\prime} \mathrm{N}, 51^{\circ} 00^{\prime} \mathrm{E}, 1360 \mathrm{~m}, 25 . \mathrm{V} .-8$. VI.2008, leg. Skale (NME). Lorestan: 24 exs., $35 \mathrm{~km}$

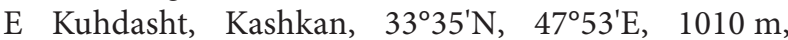
17.X.2011, leg. Frisch (MNHUB, cAss); 3 exs., 30 km E Kuhdasht, 33³5'N, 4751'E, 1080 m, 17.X.2011, leg. Frisch (MNHUB). Ilam: 3 exs., Sarableh-Kuhdasht,

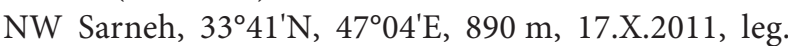
Frisch (MNHUB, cAss); 1 ex., $10 \mathrm{~km} \mathrm{NW}$ Eyvan, $5 \mathrm{~km}$ W Alamdar, $33^{\circ} 52^{\prime} \mathrm{N}, 46^{\circ} 11^{\prime} \mathrm{E}, 1170 \mathrm{~m}, 18 . \mathrm{X} .2011$, leg. Frisch (MNHUB). Gilan: 2 우, S Astara, Lavandvil, $38^{\circ} 18^{\prime} \mathrm{N}, 48^{\circ} 50^{\prime} \mathrm{E}, 30 \mathrm{~m}, 10 . \mathrm{X} .2011$, leg. Frisch (MNHUB).

Comment: Sunius fulgocephalus is widespread in the Caucasus region and has been recorded from Armenia, Georgia, Azerbaijan, and Iran. For a distribution map see Assing (2008a).

\section{Sunius iranicus Assing, 2002}

Material examined: Iran: $10^{*}$ [brachypterous], Ilam province, $10 \mathrm{~km} \mathrm{~S}$ Ilam City, $33^{\circ} 34^{\prime} \mathrm{N}, 46^{\circ} 25^{\prime} \mathrm{E}, 1300 \mathrm{~m}$, 19.X.2011, leg. Frisch (MNHUB); 8 exs. [brachypterous], Yasd province, SW Taft, Dehbala, $31^{\circ} 34^{\prime} \mathrm{N}, 54^{\circ} 07^{\prime} \mathrm{E}, 2760$, 17.V.2010, leg. Frisch \& Serri (MNHUB, cAss); 5 exs. [1 9 macropterous], Kerman province, Bardsir-Baft, $10 \mathrm{~km}$ SE Qal'eh Askar, 2928'N, 56²43'E, 2950 m, 22.V.2010, leg. Frisch \& Serri (MNHUB, cAss).

Comment: The known distribution of S. iranicus is confined to Iran (Assing 2008a).

\section{Sunius nigrinus (EPPELSHEIM, 1892)}

Material examined: Kyrgyzstan: 2 exs., Batken, IsfanaIsfara, WSW Ozgorush, $39^{\circ} 44^{\prime} \mathrm{N}, 70^{\circ} 00^{\prime} \mathrm{E}, 1560 \mathrm{~m}$, 23.VI.2012, leg. Frisch (MNHUB); 1 ex., Batken, S Quvasoy, Majdan, $40^{\circ} 05^{\prime} \mathrm{N}, 72^{\circ} 04^{\prime} \mathrm{E}, 1370 \mathrm{~m}, 17 . \mathrm{VI} .2012$, leg. Frisch (MNHUB); 1 ex., Batken, W Majdan, Chochko-Say, $40^{\circ} 03^{\prime} \mathrm{N}, 72^{\circ} 02^{\prime} \mathrm{E}, 1640 \mathrm{~m}, 18 . \mathrm{VI} .2012$, leg. Frisch (cAss); 1 ex., Jalal Abad, NE Kara-Kul, ESE Kekbel, Karasu river, $41^{\circ} 41^{\prime} \mathrm{N}, 72^{\circ} 59^{\prime} \mathrm{E}, 1230$ m, 2.VII.2012, leg.
Frisch (MNHUB); 1 ex., NE Kara-Kul, N Kekbel, Kekbel pass, $41^{\circ} 43^{\prime} \mathrm{N}, 72^{\circ} 55^{\prime} \mathrm{N}, 1420 \mathrm{~m}, 2 . \mathrm{VII} .2012$, leg. Frisch (cAss).

Comment: This species is widespread and not uncommon in Middle Asia. Its distribution is mapped in Assing (2008a).

\section{Sunius kastcheevi Assing, 2008}

Material examined: Kyrgyzstan: $1 \sigma^{\star}$, Chui, S Tokmok, $3 \mathrm{~km}$ E Kyzyl-Suu, Kichi-Almaluu-Say, $42^{\circ} 43^{\prime} \mathrm{N}, 75^{\circ} 32^{\prime}$, 23.VI.2013, leg. Frisch (MNHUB).

Comment: The original description of this recently described species is based on material from Kazakhstan (Assing 2008a). The above male represents the first record from Kyrgyzstan.

\section{Sunius rubriceps Assing, 2011}

Material examined: Iran: $10^{\star}$, Kerman province, BardsirBaft, $10 \mathrm{~km} \mathrm{SE}$ Qal'eh Askar, $29^{\circ} 26^{\prime} \mathrm{N}, 56^{\circ} 45^{\prime} \mathrm{E}, 3360 \mathrm{~m}$, 22.V.2010, leg. Frisch \& Serri (MNHUB).

Comment: The distribution of S. rubriceps is confined to southern Iran (Assing 2011b).

\section{Sunius sinaicus (CoIfFAIt, 1961)}

Material examined: Saudi Arabia: 1 \% , Hesua, 610 m, 27.IX.1981, leg. Büttiker (NHMB); 1 \%, Khashm Khafs, 13.III.1981, leg. Büttiker (cAss).

Comment: Sunius sinaicus is distributed in the Middle East, where the species has been recorded from Saudi Arabia, Egypt (Sinai Peninsula), and Oman (Assing 2008a).

\section{Sunius acutissimus Assing, 2008}

Material examined: Kyrgyzstan: 4 exs. [1 teneral], Batken, NE Isfana, N Suljukta, Bulak-Bashi, $39^{\circ} 58^{\prime} \mathrm{N}, 69^{\circ} 35^{\prime} \mathrm{E}$, 980 m, 26.VI.2012, leg. Frisch (MNHUB, cAss); 1 ex., Batken, S Quvasoy, Majdan, $40^{\circ} 05^{\prime} \mathrm{N}, 72^{\circ} 04^{\prime} \mathrm{E}, 1370 \mathrm{~m}$, 17.VI.2012, leg. Frisch (MNHUB); 1 ex., Batken, SE Isfana, Dinau, $39^{\circ} 42^{\prime} \mathrm{N}, 69^{\circ} 22^{\prime} \mathrm{N}, 1770 \mathrm{~m}, 24$. VI.2012, leg. Frisch (MNHUB); 1 ex., Batken, Isfana-Isfara, WSW Ozgorush, $39^{\circ} 44^{\prime} \mathrm{N}, 70^{\circ} 00^{\prime} \mathrm{E}, 1560 \mathrm{~m}, 23 . \mathrm{VI} .2012$, leg. Frisch (cAss); 2 exs., Batken, W Majdan, Yavan-Say, $40^{\circ} 02^{\prime} \mathrm{N}, 72^{\circ} 05^{\prime} \mathrm{E}$, 1350 m, 16.VI.2012, leg. Frisch (MNHUB, cAss); 1 ex., Talas, NW Toktogul, Chychkan river, $42^{\circ} 07^{\prime} \mathrm{N}, 72^{\circ} 48^{\prime} \mathrm{E}$, 1680 m, 3.VII.2012, leg. Frisch (MNHUB); 2 exs., Jalal Abad, ESE Toktogul, Torkent, $41^{\circ} 51^{\prime} \mathrm{N}, 73^{\circ} 10^{\prime} \mathrm{E}, 960 \mathrm{~m}$, 
2.VII.2012, leg. Frisch (MNHUB); 3 exs., Jalal Abad, E. Torkent, Kosh-Tyube valley, Kara-Djigach, $41^{\circ} 48^{\prime} \mathrm{N}$, $73^{\circ} 16^{\prime} \mathrm{E}, 1010 \mathrm{~m}, 13 . \mathrm{VI} .2012$, leg. Frisch (MNHUB, cAss).

Comment: This recently described species had been recorded from Tajikistan, Turkmenistan, and Uzbekistan (Assing 2008a). The above material represents the first records from Kyrgyzstan.

\section{Sunius alaianus spec. nov.}

(Figs 1-6)

Type material: Holotype ơ: "Kyrgyzstan, Batken, W Karadzhigach: Karadzhigach-Say, 1560 m, N 4006'59"E 072 02 '24", 13.06.2013, leg. J. Frisch / Holotypus ơ Sunius alaianus spec. nov. det. V. Assing 2014" (cAss).

Etymology: The specific epithet is an adjective derived from the name of the mountain range where the type locality is situated and where this species is probably endemic.

Description: Small species; body length $3.1 \mathrm{~mm}$; length of forebody $1.6 \mathrm{~mm}$. Habitus as in Fig. 1. Coloration: head dark-reddish; pronotum bright-reddish; elytra dark-brown, with the anterior portion reddish; abdomen blackish; legs dark-yellowish; antennae reddish.

Head (Fig. 2) 1.03 times as long as broad; lateral margins behind eyes subparallel; punctation coarse and moderately dense, sparse in median dorsal portion; interstices without microsculpture. Eyes rather small, slightly more than half as long as postocular region in dorsal view. Antenna $1.0 \mathrm{~mm}$ long.

Pronotum (Fig. 2) 1.05 times as long as broad and 0.85 times as broad as head; punctation coarse and rather dense; interstices without microsculpture; midline rather broadly impunctate.

Elytra (Fig. 2) short and slender, 0.85 times as long as pronotum; punctation dense, rather coarse, but weakly defined. Hind wings completely reduced.

Abdomen 1.15 times as broad as elytra; punctation fine and moderately dense; interstices with distinct microreticulation; posterior margin of tergite VII without palisade fringe.

$0^{\text {t: }}$ sternite VII with weakly concave posterior margin; sternite VIII (Fig. 3) weakly transverse, with rather shallow posterior excision, otherwise unmodified; aedeagus (Figs 4-6) $0.4 \mathrm{~mm}$ long; ventral process smoothly curved and apically very acute in lateral view; internal sac with two series of numerous small sclerotized spines and with a pair of larger apical spines.

Comparative notes: Based on the external (coarse punctation) and the male sexual characters (aedeagus with two series of numerous sclerotized spines), S. alaianus undoubtedly belongs to the $S$. viator group (see Assing 2008a). Previously, only three micropterous species of this group were known, all of them distributed in Tajikistan: S. bohaci Assing, 2008, S. inflexus Assing, 2008, and S. pennatus Assing, 2008. Sunius alaianus is distinguished from all of them by the different shape of the ventral process of the aedeagus (species from Tajikistan: apical portion of aedeagus straight in lateral view) and by the shapes of the internal structures of the aedeagus. For illustrations of the three species from Tajikistan see Assing (2008a).

Distribution and natural history: The type locality is situated in the Alai range in southwestern Kyrgyzstan at an altitude of $1560 \mathrm{~m}$. The holotype was collected from a sandy stream bank below shrubs (FRISCH pers. comm.).

\section{Sunius cordiformis Assing, 2002}

Material examined: China: Gansu: $1 \sigma^{*}$, W Longnan, Min Shan, $33^{\circ} 26^{\prime} \mathrm{N}, 104^{\circ} 36^{\prime} \mathrm{E}, 1470 \mathrm{~m}$, deep cleft with scree, shrubs at N-slope, litter sifted, 5.VIII.2012, leg. Assing

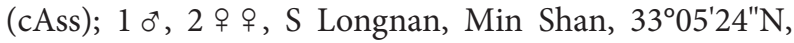
$104^{\circ} 45^{\prime} 13^{\prime} \mathrm{E}, 1500 \mathrm{~m}$, N-slope, macchia, litter and moss sifted, 6.VIII.2012, leg. Assing \& Schülke (cAss, cSch). Sichuan: 21 exs., Xiangcheng, $29^{\circ} 00^{\prime} \mathrm{N}, 9^{\circ} 46^{\prime} \mathrm{E}, 2700 \mathrm{~m}$, 29.VI.1996, leg. Smetana, Farkač \& Kabátek [C46] (cSme, cAss); $1 \mathrm{o}^{*}$, Kangding, $30^{\circ} 03^{\circ} \mathrm{N}, 103^{\circ} 02^{\prime} \mathrm{E}, 2900 \mathrm{~m}$, 2.VII.1996, leg. Smetana, Farkač \& Kabátek [C48] (cAss). Shandong: 1 \&, Taishan Nat. Res., 350 m, 19.X.1994, leg. Ji \& Wang (NHMW). Yunnan: $1 \sigma^{\star}, 6$ ㅇ $q$ : Diqing Tibet. Aut. Pref., Deqin Co., 33 km WNW Zhongdian, gully W Jinsha Jiang river, $27^{\circ} 57^{\prime} \mathrm{N}, 9^{\circ} 25^{\prime} \mathrm{E}, 2300 \mathrm{~m}, 4$.VI.2005, leg. Smetana (cSme, cAss); 1 ㅇ, Diqing Tibet. Aut. Pref., Zhongdian Co., Xue Shan $23 \mathrm{~km}$ S Zhongdian, 273' $\mathrm{N}$, 99 $42^{\prime} \mathrm{E}, 3675-3725 \mathrm{~m}, 2$.VI.2005, leg. Smetana (cAss); $1 \mathrm{o}^{\star}$, mountain NW Wuding, $25^{\circ} 37^{\prime} \mathrm{N}, 102^{\circ} 19^{\prime} \mathrm{E}, 2190 \mathrm{~m}$, degraded mixed forest with alder, oak, and pine, litter, mushrooms, and dead wood sifted, 17.VIII.2014, leg. Schülke (cSch); $1 \sigma^{\star}$, Wuding, Lion Mountain Scenic Area, $25^{\circ} 32^{\prime} \mathrm{N}, 102^{\circ} 23^{\prime} \mathrm{E}, 2200 \mathrm{~m}$, stream valley with deciduous forest, moist litter sifted, 17.VIII.2014, leg. Assing (cAss).

Comment: Sunius cordiformis is widespread in China, but was previously unknown from Gansu and Shandong (Assing 2002, 2008b, 2011b).

\section{Sunius furcillatus Assing, 2002}

Material examined: China: Gansu: $1 \sigma^{\top}, S$ Longnan, Min Shan, 3305'24"N, 104 $45^{\prime} 13^{\prime \prime E}, 1500$ m, N-slope, macchia, litter and moss sifted, 6.VIII.2012, leg. Assing (cAss).

Comment: The above male represents the first record from Gansu. 


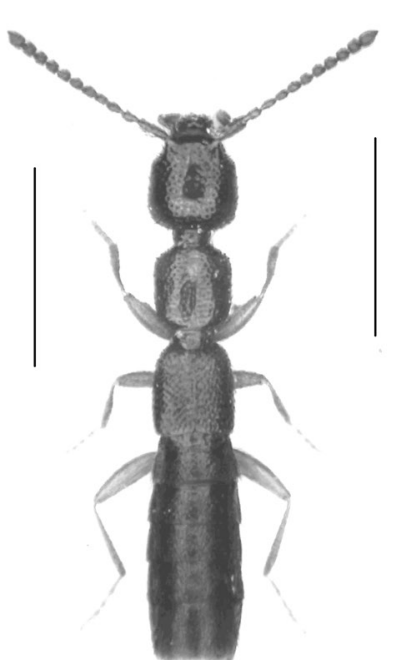

1

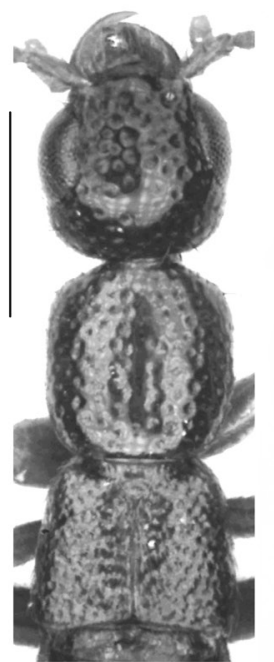

7

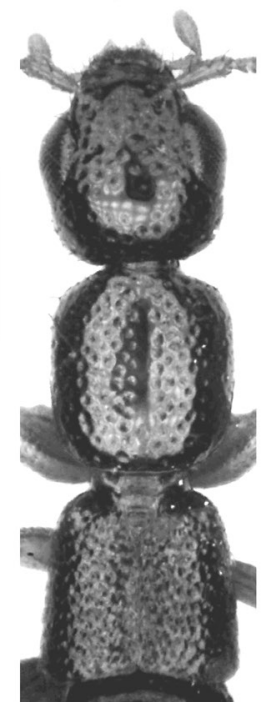

11

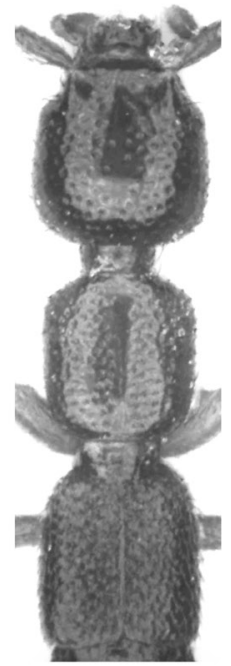

2

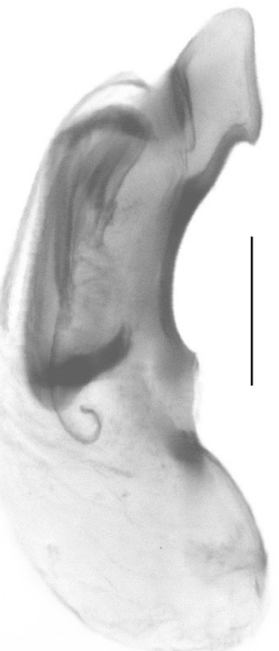

9

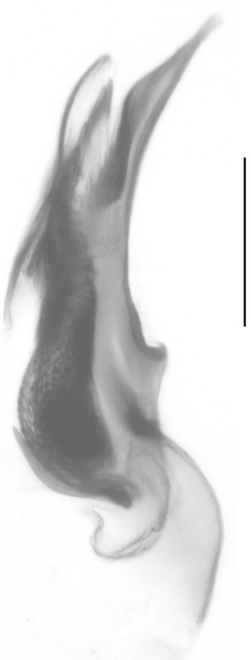

4

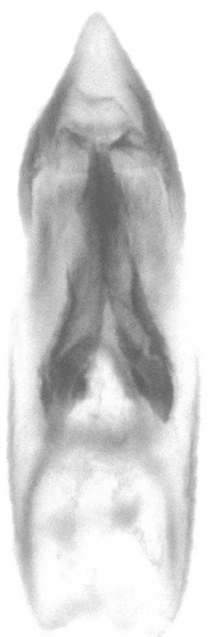

10
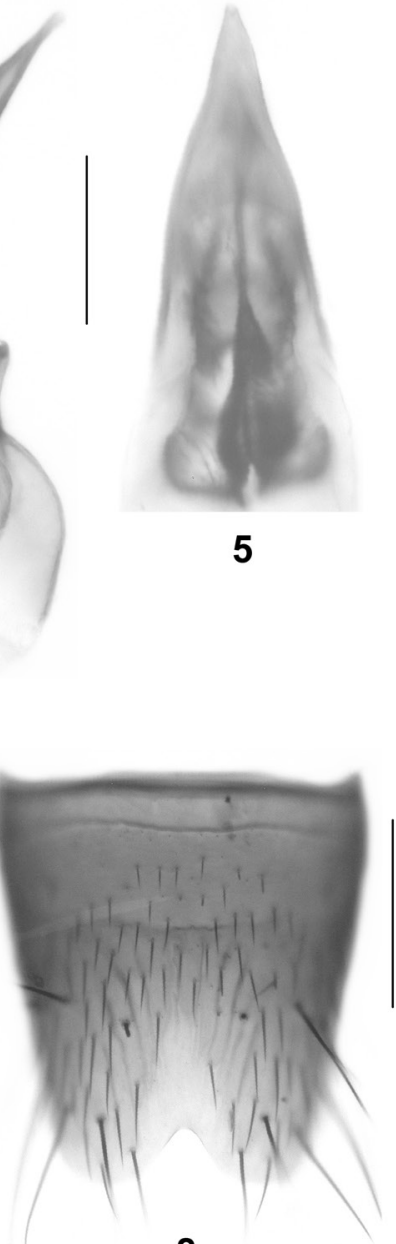

8

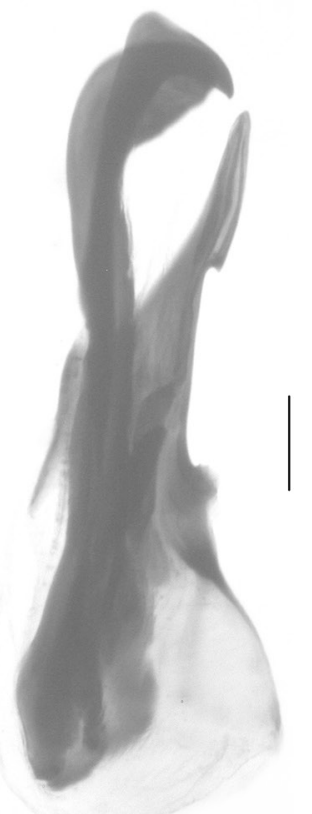

13

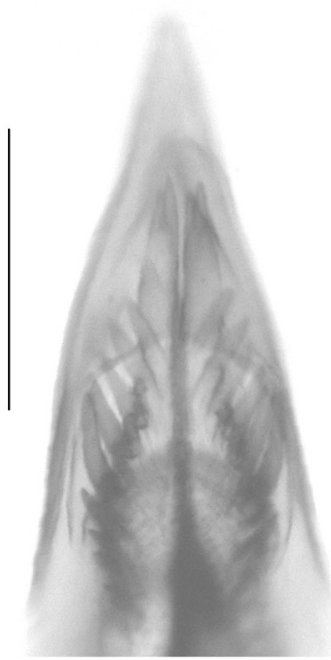

6

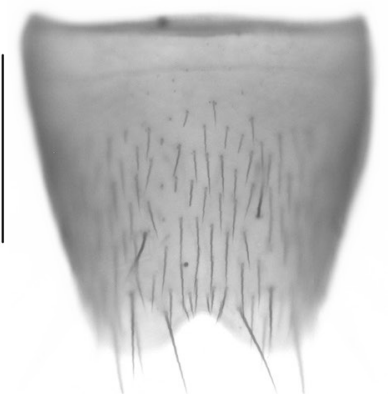

3

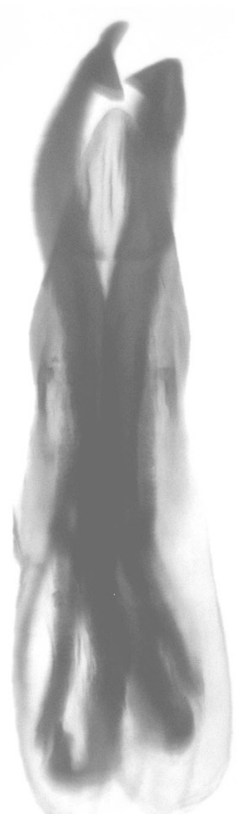

14

Figs 1-14: Sunius alaianus spec. nov. (1-6), S. marratus spec. nov. (7-10), and S. virilis spec. nov. (11-14): habitus (1); forebody (2, $7,11)$; male sternite VIII $(3,8,12)$; aedeagus in lateral and in ventral view $(4,9-10,13-14)$; ventral process of aedeagus in ventral view (5); internal structures of aedeagus in ventral view (6). Scale bars: 1: $1.0 \mathrm{~mm} ; 2,7,11: 0.5 \mathrm{~mm} ; 3,8,12: 0.2 \mathrm{~mm}$; 4-6, 9-10, 13-14: $0.1 \mathrm{~mm}$. 


\section{Sunius cameroni AssING, 2011}

Material examined: India: West Bengal: 4 exs., Darjeeling district, Tiger Hill, 2200-2300 m, 13.X.1978, leg. Besuchet \& Löbl (MHNG, cAss); 7 exs., same data, but 2500-2600 m, 18.X.1978 (MHNG); 4 exs., Darjeeling district, Tonglu, 2700 m, 16.X.1978, leg. Besuchet \& Löbl (MHNG, cAss).

Comment: Material with specified locality data was previously known only from Tiger Hill in Darjeeling district, West Bengal, India (Assing 2011b).

\section{Sunius galiberti (CoIfFAIt, 1987)}

Material examined: Nepal: 9 exs., Kathmandu district, Phulchoki, 2500 m, 28.-29.IV.1984, leg. Löbl \& Smetana (MHNG, cAss); 1 ex., Lalitpur district, Phulchoki, 2550 m, 15.X.1983, leg. Smetana \& Löbl (MHNG).

Comment: This species of the S. manasluensis group has been recorded only from Phulchoki, a mountain near Kathmandu in Central Nepal (Assing 2010, 2011b).

\section{Sunius marratus spec. nov.}

(Figs 7-10)

Type material: Holotype $\sigma^{*}$ : "INDIA W. Bengal, Darjeeling distr., Ghoom-Lopchu 2000 m, BesuchetLöbl 14.X.78 / Holotypus ơ Sunius marratus spec. nov. det. V. Assing 2015” (MHNG). Paratypes: 3 ㅇ p: same data as holotype (MHNG, cAss); 1 ㅇ, 1 ex. without abdomen: same data, but "12.X.78" (MHNG); 1 : "INDIA W. Bengal, Darjeeling distr., Ghoom $1500 \mathrm{~m}$ 15.X.78, Besuchet-Löbl" (MHNG); 1 o": "INDIA W. Bengal, Darjeeling distr., Tonglu 3100 m 16.X.78, Besuchet-Löbl" (cAss).

Etymology: The specific epithet is an adjective derived from the Latin noun marra (hoe) and alludes to the shape of the internal structures of the aedeagus.

Description: Body length 3.0-4.0 mm; length of forebody 1.6-1.7 mm. Coloration: body black; legs pale-brown with slightly darker femora; antennae pale-reddish.

Head (Fig. 7) as long as broad or weakly transverse, tapering posteriad in posterior half; punctation conspicuously coarse and dense in anterior dorsal portion, very sparse and less coarse in posterior dorsal portion; interstices without microsculpture. Eyes enormous and bulging, more than twice as long as postocular region in dorsal view.

Pronotum (Fig. 7) weakly oblong and slightly narrower than head; punctation coarse and dense; midline moderately broadly impunctate.
Elytra (Fig. 7) short, approximately 0.65 times as long as pronotum; punctation dense, irregular, and ill-defined. Hind wings completely reduced.

Abdomen slightly broader than elytra; punctation fine, moderately dense anteriorly, gradually becoming less dense towards posterior tergites; interstices with shallow microsculpture; posterior margin of tergite VII without palisade fringe.

${ }^{\top}$ : $\quad$ sternite VII without distinct modifications; sternite VIII (Fig. 8) approximately as broad as long, pubescence unmodified, posterior excision of subtriangular shape, its depth approximately one-tenth the length of sternite; aedeagus (Figs 9-10) $0.45 \mathrm{~mm}$ long; ventral process stout and of distinctive shape; internal sac with a pair of long and similarly shaped sclerotized structures.

Comparative notes: Based on the external (coarse punctation, reduced elytra and hind wings, enormous eyes) and the male sexual characters (aedeagus with a pair of conspicuously long sclerotized structures in internal sac), S. marratus belongs to the S. manasluensis group, which is distributed in the Himalaya and China, and which previously included eight species: S. manasluensis Assing, 2010 (Nepal: Manaslu), S. galiberti (Central Nepal: Phulchoki), S. turgescens Assing, 2010 (China: Yunnan), S. macrops Assing, 2010 (China: Yunnan), S. cursor Assing, 2011 (Nepal), S. baculatus Assing, 2011 (East Nepal), S. cameroni (Darjeeling), and S. bouddha (CoIffait, 1978) (Bhutan). The aedeagus of S. marratus is most similar to that of $S$. bouddha, but distinguished by the slightly different shape of the ventral process and particularly by the distinctly shorter and differently shaped internal structures. For illustrations of S. bouddha see Assing (2011b), for those of other species of the S. manasluensis group see Assing (2010, 2011a).

Distribution and natural history: The type specimens were collected in three geographically close localities in Darjeeling district, West Bengal (North India), at altitudes of 1500-3100 m.

\section{Sunius virilis spec. nov.}

(Figs 11-14)

Type material: Holotype ơ: "INDIA W. Begal, Darjeeling distr., Algarah-Labha 1900 m, Besuchet-Löbl 11.X.78 / Holotypus o Sunius virilis spec. nov. det. V. Assing 2015” (MHNG). Paratypes: 3 ㅇ + : same data as holotype (MHNG, cAss).

Etymology: The specific epithet (Latin, adjective: virile, masculine) alludes to the conspicuously long and large aedeagus.

Description: Body length 3.7-4.0 mm; length of forebody 1.8-1.9 mm. External characters (Fig. 11) similar to those of $S$. marratus, except for the slightly larger size and 
the less dense and less coarse punctation of the anterior dorsal portion of the head.

$\sigma^{*}$ : sternite VII without distinct modifications; sternite VIII (Fig. 12) distinctly oblong, nearly 1.3 times as long as broad, and with small and shallow posterior incision; aedeagus (Figs 13-14) of highly distinctive morphology, $0.8 \mathrm{~mm}$ long; ventral process of distinctive shape; internal sac with pair of enormous (length: $0.9 \mathrm{~mm}$ ), strongly sclerotized internal structures of different shapes.

Comparative notes: Like $S$. marratus, this species belongs to the $S$. manasluensis group. It differs from other species of this group by the shape of the male sternite VIII and particularly by the highly distinctive morphology of the aedeagus.

Distribution and natural history: The type locality is situated between Algarah and Labha in Darjeeling district (North India: West Bengal) at an altitude of $1900 \mathrm{~m}$.

\section{Sunius deplectens spec. nov.}

(Figs 15-18)

Type material: Holotype o ${ }^{*}$ : "INDIA W. Begal, Darjeeling distr., Algarah 1800 m 9.X.78, Besuchet-Löbl / Holotypus o Sunius deplectens spec. nov. det. V. Assing 2015" (MHNG). Paratype o ${ }^{\star}$ : same data as holotype (cAss).

Etymology: The specific epithet is the present participle of the Latin verb deplecti (to claw, to cling, to scratch) and alludes to the claw-shaped internal structures of the aedeagus.

Description: Body length 3.4-4.0 mm; length of forebody 1.8-1.9 mm. External characters (Fig. 15) similar to those of $S$. marratus, except for the slightly larger size. $0^{*}$ : sternite VII without distinct modifications; sternite VIII (Fig. 16) distinctly oblong, approximately 1.25 times as long as broad, and with a posterior incision of subtriangular shape, its depth approximately one-tenth the length of sternite; aedeagus (Figs 17-18) of distinctive morphology, approximately $0.6 \mathrm{~mm}$ long; ventral process of distinctive shape; internal sac with pair of long and similarly shaped, apically claw-shaped sclerotized structures.

Comparative notes: Sunius deplectens, too, belongs to the $S$. manasluensis group. Among the species of this group, it is characterized by the shape of the male sternite VIII, the shape of the ventral process of the aedeagus, and particularly the shapes of the internal structures of the aedeagus.

Distribution and natural history: The type locality is situated near Algarah in Darjeeling district (North India: West Bengal) at an altitude of $1800 \mathrm{~m}$.

\section{Sunius dearmatus spec. nov.}

(Figs 19-22)

Type material: Holotype ơ: "E. NEPAL: KOSI, Chichila s/Ahale, 2200 m, 24.IV.84, Löbl-Smetana / Holotypus “ Sunius dearmatus spec. nov. det. V. Assing 2015" (MHNG). Paratype ${ }^{\star}$ [forebody missing]: same data as holotype (cAss).

Etymology: The specific epithet is the past participle of the Latin verb dearmare (to disarm) and alludes to the absence of long sclerotized structures in the internal sac of the aedeagus.

Description: Body length $3.4 \mathrm{~mm}$; length of forebody $1.7 \mathrm{~mm}$. Eyes approximately twice as long as postocular region in dorsal view (Fig. 19). Other external characters similar to those of $S$. marratus.

$\sigma^{*}$ : sternite VII without distinct modifications; sternite VIII (Fig. 20) weakly oblong, posterior excision small and shallow, less than one-tenth as deep as the length of sternite; aedeagus (Figs 21-22) of distinctive morphology, approximately $0.5 \mathrm{~mm}$ long; ventral process of distinctive shape; internal sac only with short and moderately sclerotized structures.

Comparative notes: Based on the external and male sexual characters, S. dearmatus belongs to the S. manasluensis group. It differs from other species of this group by the shape of the male sternite VIII and particularly by the morphology of the aedeagus.

Distribution and natural history: The type locality is situated in Kosi province, East Nepal, at an altitude of $2200 \mathrm{~m}$.

\section{Sunius migrus spec. nov.}

(Figs 23-26)

Type material: Holotype o : "NEPAL, Kathmandu District / Phulcoki 2600 m, 20.IV.1982, A. \& Z. Smetana / Holotypus o Sunius migrus spec. nov. det. V. Assing 2015" (MHNG). Paratypes: 4 우 우 "NEPAL: distr. Kathmandu, Phulcoki 2500 m, 28-29.IV.84, Löbl-Smetana” (MHNG, cAss).

Etymology: The specific epithet (Latin, adjective: small) alludes to the relatively small body size, one of the characters distinguishing this species from the sympatric S. galiberti.

Description: Body length 3.0-3.8 mm; length of forebody 1.5-1.7 mm. External characters (Fig. 23) similar to those of $S$. marratus.

$\sigma^{*}$ : sternite VII without distinct modifications; sternite VIII (Fig. 24) weakly oblong, posterior excision moderately large, approximately 0.15 times as deep as 
length of sternite; aedeagus (Figs 25-26) of distinctive morphology, $0.57 \mathrm{~mm}$ long; ventral process slender; internal sac with dark membranous structure, but without pair of sclerotized spines.

Comparative notes: Sunius migrus differs from all other species of the S. manasluensis group by the shape of the male sternite VIII and above all by the distinctive morphology of the aedeagus (shapes of ventral process and of internal structures). It is additionally distinguished from the sympatric $S$. galiberti by the smaller and more slender body (S. galiberti: length of forebody $1.8-1.9 \mathrm{~mm})$.
Distribution and natural history: The type locality is situated on Phulchoki, a mountain near Kathmandu in Central Nepal. The altitudes range from 2500 to $2600 \mathrm{~m}$.

\section{Acknowledgements}

My gratitude is due to the colleagues listed in the material section for the loan of specimens from the collections under their care. Johannes Frisch (MNHUB) granted permission to retain the holotype of Sunius alaianus in exchange for a holotype of Scopaeus. Benedikt Feldmann (Münster) proof-read the manuscript.

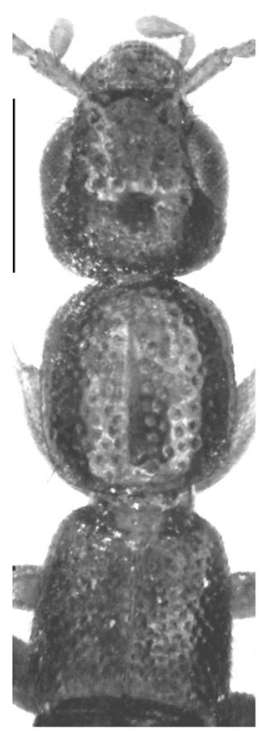

15

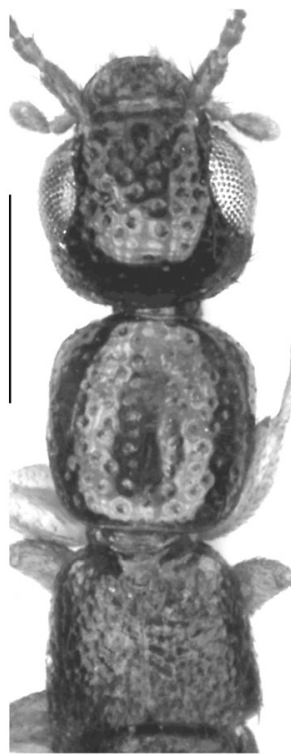

23

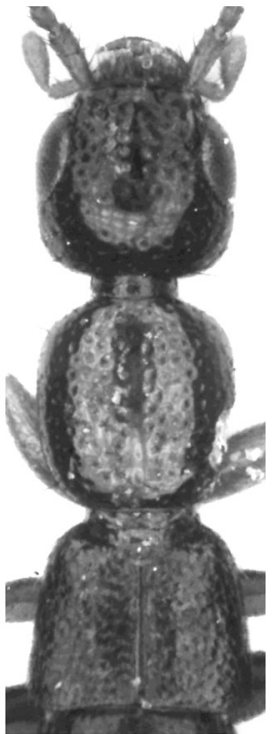

19

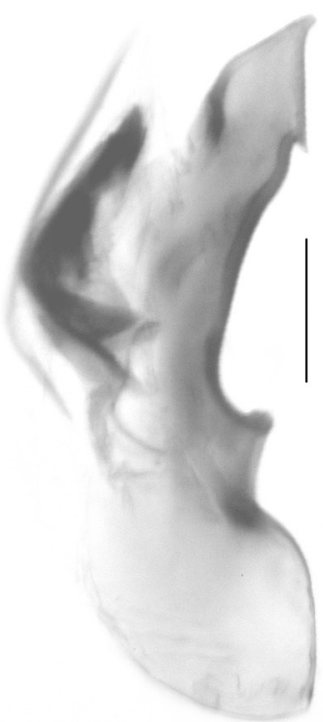

21

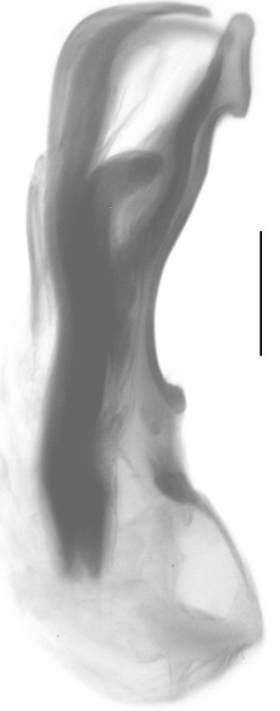

17

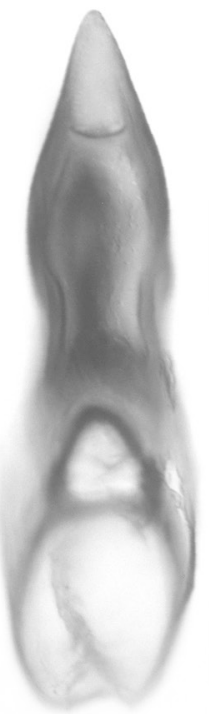

22

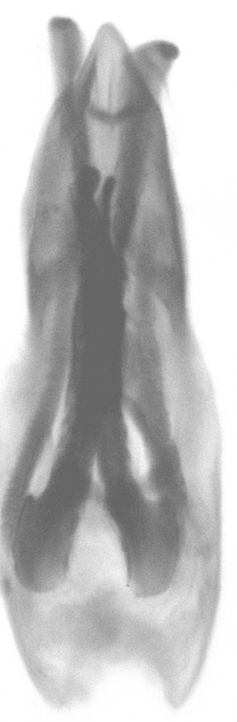

18

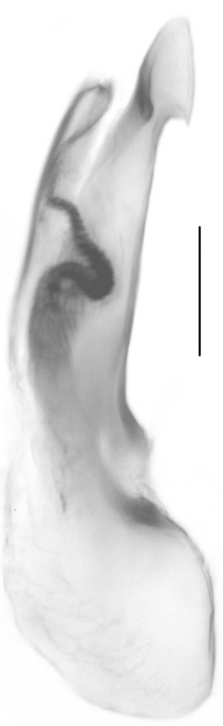

25

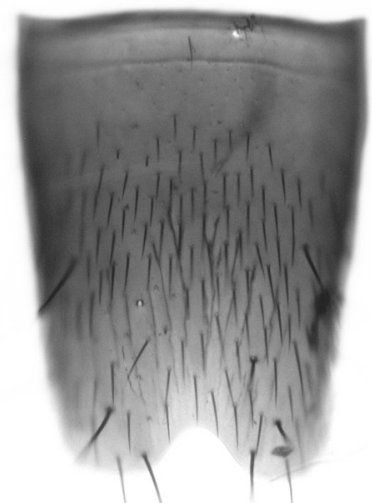

16
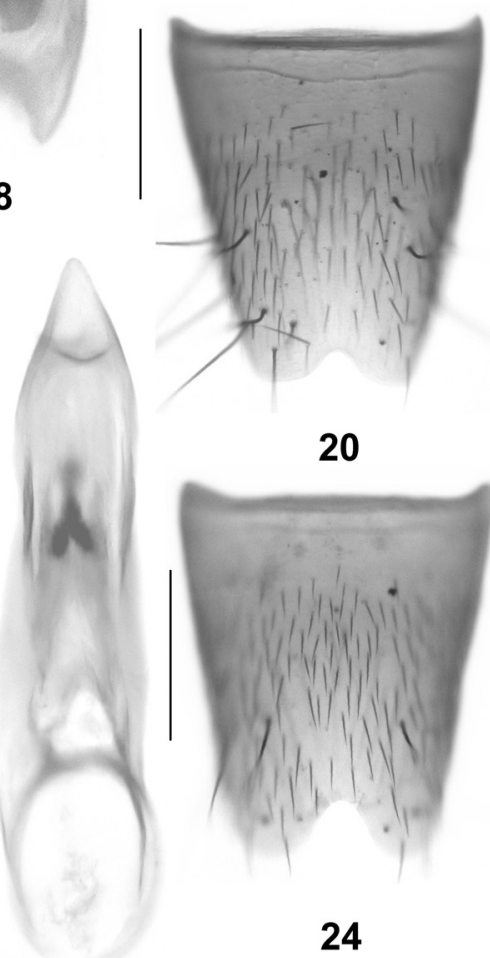

20

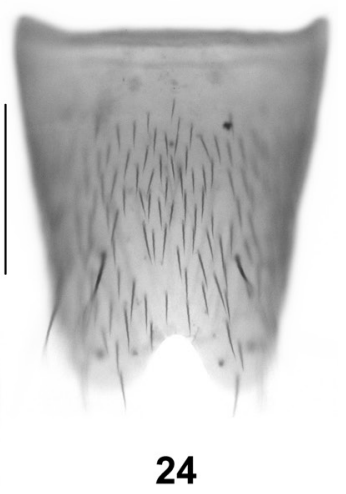

26

Figs 15-26: Sunius deplectens spec. nov. (15-18), S. dearmatus spec. nov. (19-22), and S. migrus spec. nov. (23-26): forebody (15, 19, 23); male sternite VIII $(16,20,24)$; aedeagus in lateral and in ventral view (17-18, 21-22, 25-26). Scale bars: 15, 19, 23: 0.5 mm; 16, 20, 24: $0.2 \mathrm{~mm} ; 17-18,21-22,25-26: 0.1 \mathrm{~mm}$. 


\section{References}

Assing, V.2002: New species of Sunius CurTis from China and Iran (Coleoptera: Staphylinidae, Paederinae). Linzer Biologische Beiträge 34 (1): 289-296.

Assing, V. 2008a: A revision of the Sunius species of the Western Palaearctic region and Middle Asia (Coleoptera: Staphylinidae: Paederinae). - Linzer Biologische Beiträge 40 (1): 5-135.

Assing, V. 2008b: Four new species and additional records of Palaearctic Sunius, with two new synonymies (Coleoptera: Staphylinidae: Paederinae). - Beiträge zur Entomologie, Keltern 58 (2): 455-470.

Assing, V. 2010: A revision of Palaearctic Sunius. XII. New species, new synonymies, and additional records (Coleoptera: Staphylinidae: Paederinae). - Linzer Biologische Beiträge 42 (2): 1045-1061.

Assing, V. 2011a: A revision of the genus Neosclerus Cameron (Coleoptera: Staphylinidae: Paederinae). - Beiträge zur Entomologie, Keltern 61 (1): 89-148.

Assing, V. 2011b: The Sunius species of the Palaearctic region (Coleoptera: Staphylinidae: Paederinae). Linzer Biologische Beiträge 43 (1): 151-193.
Assing, V. 2011c: A revision of Palaearctic Sunius XIV. Three new species from Turkey and additional records (Coleoptera: Staphylinidae: Paederinae). Linzer Biologische Beiträge 43 (2): 1159-1168.

Assing, V. 2013a: On the Staphylinidae (Coleoptera) of Crete, Greece. - Stuttgarter Beiträge zur Naturkunde A, Neue Serie 6: 83-102.

Assing, V. 2013b: On the Staphylinidae of Rhodes, Greece (Insecta: Coleoptera). - Linzer Biologische Beiträge 45 (2): 1587-1613.

Assing, V. 2015: On the Staphylinidae (Coleoptera) of Crete II. Seven new species, a new synonymy, and additional records. - Stuttgarter Beiträge zur Naturkunde A, Neue Serie 8: 95-112.

Assing, V. in press: On the Staphylinidae of Samos (Insecta: Coleoptera). - Koleopterologische Rundschau 85 (2015). 